\title{
Metabolic characteristics and nutrition intake on women with normal body mass index
}

\author{
1,2, ${ }^{*}$ Fitranti, D.Y., ${ }^{1,2}$ Dieny, F.F., ${ }^{1,2}$ Kurniawati, D.M., ${ }^{1,2}$ Purwanti, R., \\ ${ }^{1}$ Kusumaningnastiti, B. and ${ }^{1}$ Safitri, I. \\ ${ }^{1}$ Nutrition Science Department, Faculty of Medicine, Diponegoro University, Jln. Prof Soedarto SH, \\ Tembalang, Semarang, 50275 \\ ${ }^{2}$ Center of Nutrition Research (CENURE) Jln. Prof Soedarto SH, Tembalang, Semarang, 50275
}

\author{
Article history: \\ Received: 29 December 2019 \\ Received in revised form: 15 \\ February 2020 \\ Accepted: 7 March 2020 \\ Available Online: 30 May \\ 2020
}

Keywords:

MONW,

Normal BMI,

Metabolic syndrome,

Nutrition intake

DOI:

https://doi.org/10.26656/fr.2017.4(S3).S13

\begin{abstract}
Metabolic syndrome can be found on an individual with normal weight (Metabolically Obese Normal Weight/MONW). Eating habits and lifestyle changing in early adulthood can be the risk of metabolic syndrome in person with a normal body mass index (BMI). The purpose of this study was to identify metabolic characteristics in women with normal BMI and to analyze the correlation of nutrition intake with metabolic syndrome on women with normal BMI. This is an observational study with a cross-sectional design at five offices in Semarang. The sample in this study was 64 subjects. Inclusion criteria of study subject were women aged $25-40$ years and BMI $<25 \mathrm{~kg} / \mathrm{m}^{2}$. Study subject was chosen by using a consecutive sampling method. The data of nutrition intake was obtained by using the Food Frequency Questionnaire. HDL cholesterol, fasting blood glucose and triglyceride were analyzed. Analysis data was conducted by using Pearson correlation and Rank Spearman. MONW was present in $10.9 \%$ and more than $50 \%$ had pre metabolic syndrome. A total of $51.6 \%$ of the subjects had central obese and $26.6 \%$ had low HDL cholesterol. About $14.1 \%$ of the subjects have hypertension. There was a positive correlation between energy, fat intake and waist circumference. Carbohydrate intake was positively correlated with fasting blood glucose and triglyceride. The higher protein intake, the higher HDL cholesterol. The most common indicator of metabolic syndrome on women with normal BMI was central obesity and low HDL cholesterol. The factors related to the prevalence of metabolic syndrome on women with normal BMI was macronutrient intake.
\end{abstract}

\section{Introduction}

Adulthood is a productive age in which the body needs optimal nutrition for activities. In this period there is no increase in energy required because the growth and development have stopped (Thorpe et al., 2014; Hizni, 2016). An adult usually can earn money, it makes them tend to have more ability to choose the food they consume. It causes changes in their diet. In the other hand, an adult is required to work productively in which the activity is mostly in a position of sitting so that physical activity of adult tend to be low (Kant et al., 2013).

Diet and lifestyle changes in early adulthood can be the initiation of degenerative diseases. The study about diet conducted in Department of Health South Sulawesi showed that $62 \%$ respondents had poor diets which were high carbohydrate and fat and low fiber so that it can be one of the risk factors of degenerative diseases (Nadimin, 2011). Another study about the dietary pattern on employees of Alfa Star Buana company and PLS Ervina Medan showed that employees had poor diets which were high energy intake and low fiber as $72 \%$ (Zahra et al., 2013).

Several studies had shown that there was a correlation of dietary pattern and the impact on health parameters such as Body Mass Index (BMI), cholesterol level, and blood tension. A good diet can be a protective factor toward metabolic syndrome, cardiovascular disease, obesity and hypertension (Splett and Krinke, 2011; Sun et al., 2014). A good diet is a balanced nutrition in term of quality and quantity. The quality diet can indicate whether the food consumed is in accordance with the recommendations. High quality diet is a diet 
which can meet the nutritional needs of an individual to achieve optimum health. Balanced nutrition can keep the body in healthy without gaining weight by having high fiber, low cholesterol, low saturated fat and low sodium and adequate macronutrient (Kementrian Kesehatan Republik Indonesia, 2014; Alkerwi, 2014).

One of the nutritional problems which has a high prevalence in adulthood is metabolic syndrome (MS) in which someone with MS has minimally three metabolic disorder which indicated by the high fasting blood glucose level, hypertension, dyslipidemia, and central (Dodd, 2012; Suliga et al., 2015). One epidemiology data stated that world MS prevalence is $20-25 \%$. The result of Framingham Offspring Study found that in respondent at the age of 26-82 years, there was $29,4 \%$ male and 23.1\% female had MS (Sihombing and Tjandrarini, 2015). The data from Himpunan Studi Obesitas Indonesia (HISOBI) shows that MS prevalence in Indonesia is $13.13 \%$ (Rini, 2015). Another study conducted in Medan in 2012 describe MS prevalence on obese persons were $66 \%$ and on the nonobese persons was $28 \%$ (Mutiara, 2013).

The main factors that cause metabolic syndrome are abdominal obesity, but in fact, metabolic syndrome can also be found in individuals of normal weight. People with normal weight and metabolic syndrome are known as Metabolically Obese Normal Weight (MONW). The criteria in determining a MONW are if an individual has a normal BMI (18.5 - $\left.24.9 \mathrm{~kg} / \mathrm{m}^{2}\right)$, accompanied by (1) a minimum of three of the five criteria for metabolic syndrome, or (2) has a TyG index is above the normal limit, or (3) the results of Homeostasis Model Assessment (HOMA) test on insulin resistance is in the highest quartile (Lee et al, 2015). Research in some populations shows that non-obese adults who have metabolic syndrome have a prevalence of $14.7-59 \%$ (Suliga et al., 2015). Other studies have also shown that the prevalence of metabolic syndrome in normal-weight individuals is $17.27 \%$ (Suliga et al., 2016). About $24 \%$ of the adult population in America has a diagnosis of MONW is at risk of developing chronic disease (Bradshaw et al., 2013). The study about prevalence and characteristic metabolic of women with normal BMI is still rarely done. Previous studies in Norway aimed to analyze the relationship between dietary pattern qualitatively with the prevalence of metabolic syndrome in normal weight (Suliga et al., 2015). In this study, the metabolic characteristics of women with MONW were studied and the correlation between nutrition intake quantitatively and metabolic syndrome in normal weight were studied.

\section{Materials and methods}

This was an observational study with cross sectional design in 5 offices in Semarang city which was Balai Besar Teknologi Pencegahan Pencemaran Industri (BBTPPI), Dinas Pekerjaan Umum (DPU), Dinas Perindustrian dan Perdagangan (Disperindag), Dinas Tenaga Kerja dan Perhutani. The study was conducted in May-October 2018. The sample size in this study was 64 subjects. Inclusion criteria for the subjects of this study were women aged $25-40$ years, BMI $<25 \mathrm{~kg} / \mathrm{m}^{2}$, not currently undergoing a special diet, not pregnant, not smoking and drinking alcoholic beverages and were willing to participate in the study by filling the Informed Consent form. The subjects were taken by consecutive sampling. The independent variable was nutrition intake consisting of energy, protein, fat, carbohydrate, fiber and sodium intake. The dependent variable was metabolic syndrome components.

The intake of energy, protein, fat, carbohydrates, fiber and sodium is the average intake of energy, protein, fat, carbohydrates, fiber and sodium in a day from food, drinks and supplements obtained by interviewing food intake in the past 1 month using the Semi Quantitative Food Frequency (SQ FFQ) method. Data on food intake collected was then analyzed using Nutrisurvey software. An adequate level of energy of protein, fat, carbohydrate, fiber and sodium was obtained by comparing the intake of nutrients with individual needs. Metabolic syndrome was a clinical condition where there are a number of metabolic disorders, namely insulin resistance, dyslipidemia (high triglyceride levels and low levels of high-density lipoprotein (HDL)), high blood pressure and central obesity. Fasting blood glucose was categorized as high when it was $\geq 100 \mathrm{mg} / \mathrm{dL}$. Waist circumference was categorized at risk to health if it was $>80 \mathrm{~cm}$ (women). Triglyceride level was categorized to be high when $\geq 150 \mathrm{mg} / \mathrm{dL}$ and HDL was expressed low when it was $<50$ (women). Hypertension was defined when blood pressure $>120 / 80 \mathrm{mmHg}$. Subjects were categorized as metabolic syndrome if they had at least 3 of 5 signs. Blood pressure was measured with the use of the blood pressure monitor Omron. The test was carried out on the artery of the left upper arm. The average of the two measurements was analyzed. Blood samples were collected by vein puncture after an overnight fast. All samples were analyzed in a commercial laboratory in Semarang city, Indonesia with the standard methods.

Univariate analysis was used to describe the frequency distribution table of the studied variables. Bivariate analysis is used to determine the correlation between the independent variables and the dependent variable. Bivariate analysis was conducted by using Chi- 
Square test. Data analysis was conducted using SPSS.

\section{Results}

The subjects were sixty-four women with a mean age of 31 years and a mean BMI of $22.31 \mathrm{~kg} / \mathrm{m}^{2}$ (Table 1). Meanwhile, the average waist circumference of the subject was $79.28 \mathrm{~cm}$ with a minimal value of $68 \mathrm{~cm}$ and a maximal value of $90.5 \mathrm{~cm}$. The mean waist circumference of the subjects was almost $80 \mathrm{~cm}$ where the value was the cut off point for the metabolic syndrome indicator according to NCEP-ATP III for Asians (Thomas et al., 2005). The average fasting blood glucose level of the subject was only $81.28 \mathrm{mg} / \mathrm{dL}$ with the highest value of $111 \mathrm{mg} / \mathrm{dL}$.

As an indicator of dyslipidemia, the mean of triglycerides level for all subjects was $77.27 \mathrm{mg} / \mathrm{dL}$ with a high standard deviation as $31.97 \mathrm{mg} / \mathrm{dL}$ which means that the triglyceride values in this study varied greatly. This is evidenced by the lowest triglyceride level which was $21 \mathrm{mg} / \mathrm{dL}$ while the highest value was $221 \mathrm{mg} / \mathrm{dL}$. However, this is very different from the HDL level. The mean of HDL cholesterol level of the subjects was 54.88 $\mathrm{mg} / \mathrm{dL}$ with the lowest value of $37 \mathrm{mg} / \mathrm{dL}$ and the highest value of $77 \mathrm{mg} / \mathrm{dL}$. This mean was above the cut-off point indicator of metabolic syndrome for HDL which is $<50 \mathrm{mg} / \mathrm{dL}$ (Thomas et al., 2005). Meanwhile, the subjects have a mean systolic blood pressure value of $106 / 72 \mathrm{mmHg}$ where this value is normal compared to the cut-off point indicator of metabolic syndrome for blood pressure that was $135 / 85 \mathrm{mmHg}$ (Thomas et al., 2005).

Mean of all nutrition intake was above $70 \%$ of total Calories, except for fiber intake which was only $50.58 \%$. Interestingly, all variables have a standard deviation of more than $16 \%$. This showed that all nutrition intake levels have a high variation in values and have a wide range between the minimum and maximum values. For example the adequacy level of fiber intake which has the lowest value of $16.56 \%$ while the highest value was $198.5 \%$.

About $11 \%$ of subjects were classified as metabolic syndrome and $51.6 \%$ were classified as pre-metabolic syndrome (Table 2). About $37.5 \%$ of the subjects have no sign of metabolic syndrome. Among the five indicators of metabolic syndrome, waist circumference is an indicator of metabolic syndrome with the highest proportion of $51.6 \%$ compared to fasting blood glucose levels, triglyceride levels, HDL cholesterol levels, and blood tension. This means that half of the subjects included central obesity or had a waist circumference of more than $80 \mathrm{~cm}$. In contrast, fasting blood glucose and triglyceride level was no more than $4 \%$. Meanwhile, from all subjects, only $14.1 \%$ had blood tension above $130 / 85 \mathrm{mmHg}$ and $26.6 \%$ of them had HDL cholesterol level $<50 \mathrm{mg} / \mathrm{dL}$.

Among all the intake variables, only the energy and macronutrient intake variables are related to the metabolic syndrome indicator. Meanwhile, the intake of fiber, sodium, saturated fat, and unsaturated fat had no correlation with metabolic syndrome indicators. Pearson correlation test results that the energy and fat intake is significantly correlated with waist circumference. Carbohydrate intake positively related to fasting blood glucose and triglyceride levels. Interestingly, Protein intake has a correlation with HDL cholesterol levels. Meanwhile, there was no intake variable correlated with blood tension.

\section{Discussion}

Metabolic syndrome is a clinical condition where

Table 1. Characteristic of subject

\begin{tabular}{lccc}
\hline \multicolumn{1}{c}{ Variable } & Mean $\pm \mathrm{SD}$ & Minimum & Maximum \\
\hline Age (year) & $31.12 \pm 4.83$ & 25 & 40 \\
Body Mass Index $\left(\mathrm{kg} / \mathrm{m}^{2}\right)$ & $22.31 \pm 1.9$ & 18 & 24,90 \\
Waist circumference $(\mathrm{cm})$ & $79.28 \pm 5.14$ & 68 & 90,5 \\
Fasting Blood glucose (mg/dl) & $81.28 \pm 9.19$ & 60 & 111 \\
Triglyceride (mg/dl) & $77.27 \pm 31.97$ & 21 & 221 \\
HDL Cholesterol (mg/dl) & $54.88 \pm 9.34$ & 37 & 77 \\
Systolic blood tension (mmHg) & $106.25 \pm 13.97$ & 90 & 135 \\
Diastolic blood tension (mmHg) & $72.34 \pm 9.92$ & 60 & 100 \\
Energy intake (\%) & $91.15 \pm 19.47$ & 49.03 & 130.75 \\
Carbohydrate intake (\%) & $86.29 \pm 16.92$ & 47.06 & 117.58 \\
Protein intake (\%) & $73.39 \pm 22.67$ & 39.66 & 157.26 \\
Fat intake (\%) & $90.05 \pm 17.67$ & 40.46 & 124.71 \\
Fiber intake (\%) & $50.58 \pm 28.80$ & 16.56 & 198.5 \\
Sodium intake (\%) & $81.75 \pm 42.75$ & 15.85 & 187.67 \\
Saturated Fat intake (\%) & $152.04 \pm 44.20$ & 62.09 & 250.58 \\
Unsaturated fat intake (\%) & $81.7142 \pm 29.31$ & 36.27 & 167.55 \\
\hline
\end{tabular}


Table 2. Description of metabolic syndrome of study subject

\begin{tabular}{clc}
\hline Metabolic Syndrome Indicators & \multicolumn{1}{c}{ Category } & $\mathrm{n}(\%)$ \\
\hline \multirow{2}{*}{ Metabolic Syndrome } & Non- Metabolic Syndrome & $24(37.5)$ \\
& Pre- Metabolic Syndrome & $33(51.6)$ \\
& Metabolic Syndrome & $7(10.9)$ \\
\hline \multirow{2}{*}{ Waist circumference } & Normal & $31(48.4)$ \\
& Obese & $33(51.6)$ \\
\hline \multirow{2}{*}{ Fasting Blood Glucose } & Normal & $63(98.4)$ \\
& High & $1(1.6)$ \\
\hline \multirow{2}{*}{ Triglyceride } & Normal & $62(96.9)$ \\
& High & $2(3.1)$ \\
\hline \multirow{2}{*}{ HDL Cholesterol } & Normal & $47(73.4)$ \\
& Low & $17(26.6)$ \\
\hline \multirow{2}{*}{ Blood Tension } & Normal & $55(85.9)$ \\
& Hypertension & $9(14.1)$ \\
\hline
\end{tabular}

there are a number of metabolic disorders, those are insulin resistance, dyslipidemia (high triglyceride levels and low levels of high density lipoprotein (HDL)), high blood tension and central obesity. According to NCEP ATP III for Asians, a person is considered to have metabolic syndrome when there are signs of at least 3 out of 5 signs of metabolic disorders; those are fasting blood glucose $\geq 100 \mathrm{mg} / \mathrm{dL}$, waist circumference $\geq 90 \mathrm{~cm}$ for men and $\geq 80 \mathrm{~cm}$ for women, triglycerides levels $\geq 150$ $\mathrm{mg} / \mathrm{dL}, \mathrm{HDL}$ cholesterol levels $<50$ (women), and blood tension $\geq 130 / 85 \mathrm{mmHg}$ (Thomas et al., 2005).

Most people with central obesity had metabolic syndrome, but in fact, metabolic syndrome can also be found in individuals of normal weight. St-Onge et al. (2004) in his study stated that in the United States, $4.6 \%$ of normal weight men and $6.2 \%$ of normal weight women had metabolic syndrome. Meanwhile, the prevalence of metabolic syndrome in the Iranian population with normal weight was higher compared to the United States of America which is $9.9 \%$ on men and $11.0 \%$ on women. Whereas in East Asia, a crosssectional study conducted in a non-obese Taiwan population showed that $18.7 \%$ of nonobese subjects had metabolic syndrome (Geetha et al., 2011). This study showed that women aged 25-40 years with normal BMI who had a metabolic syndrome of $10.9 \%$.

Characteristics of the components of metabolic syndrome that mostly occur in women with normal BMI $\left(<25 \mathrm{~kg} / \mathrm{m}^{2}\right)$ in this study are having waist circumference above the normal limit (51.6\%) and low HDL cholesterol levels $(26.6 \%)$ (Table 2), while other components such as fasting blood glucose, triglyceride levels, and blood pressure do not frequently occur in the subject. It was reported by $\mathrm{He}$ et al. (2015) that increased waist circumference and low levels of HDL cholesterol are correlated with visceral fat accumulation causing central obesity. Central obesity is correlated with excessive release of non-esterified fatty acids in the liver so that it can induce insulin resistance. The presence of insulin resistance results in an increase in HDL catabolism and interference with HDL particle maturation. Thus, the presence of central obesity was accompanied by low levels of HDL (He et al., 2015).

Bivariate analysis showed that there was a significant relationship between waist circumference with adequate levels of energy and fat intake. The results of this study are similar to those of Nikbazm et al. (2013) where a positive correlation was found between waist circumference with energy intake and fat intake on women. Another study by Burini et al. (2017) also showed a significant relationship between waist circumference with total energy intake, with a weak positive correlation. Meanwhile, the correlation value between waist circumference with energy and fat intake respectively 0.464 and 0.443 which means it has a moderate positive correlation. It means that the higher the total energy and fat intake, the greater the subject's waist circumference would be.

Limitation of total dietary fat intake as a "low fat" diet concept is usually accompanied by a limitation of total calories. Low-fat diets accompanied by energy restrictions are known to be effective in improving metabolic syndrome parameters, including body composition, blood tension, plasma lipids, inflammatory markers, and insulin sensitivity (Andersen and Fernandez, 2013). Research in 50 obese male and female subjects with metabolic syndrome given the hypocaloric diet $(500 \mathrm{kcal} /$ day $)$ by consuming whole wheat for 12 weeks has a significant decrease in waist circumference, weight, and body fat percentage (Katcher et al., 2008).

Low-fat diets without limiting energy intake can actually increase plasma triglycerides and reduce HDL levels, thus increasing the risk of metabolic syndrome. Likewise, high fat diets without carbohydrate restriction can also increase poor metabolic output. Interestingly, 
high-fat diets ( $42 \%$ of total energy) has been shown to change adipocyte progenitor cell populations and gene expression profiles in mice. In addition to impairing glucose tolerance and insulin sensitivity, high-fat feeding reduces the population of adipocyte progenitor cells in thermogenic brown adipose tissue, while also increasing vascular dysfunction and oxidative stress in the arteries of perivascular adipose tissue. Based on these findings, it may be necessary to consider optimizing the intake of fatty acids (saturated or unsaturated) rather than reducing total fat intake in the treatment of metabolic syndrome (Andersen and Fernandez, 2013).

It is known from the correlation test, carbohydrate intake has a significant correlation with fasting blood glucose and triglyceride levels (Table 3 ). This is similar to the research of Song et al. which shows that triglyceride, HDL, and fasting blood glucose levels are related to the percentage of energy from carbohydrates in men and white rice intake in women. While some studies in Asian populations found that carbohydrate consumption has a stronger correlation with metabolic syndrome in women than men (Song et al., 2014).

A study conducted on animal had shown that limiting carbohydrate intake has beneficial effects on several parameters of the metabolic syndrome. Hypertriglyceridemia mice as a metabolic syndrome model given high intake of sucrose showed increased VLDL secretion, decreased oxidation of free fatty acids (FFA), and increased synthesis of de novo FFA synthesis from glucose. But the opposite effect occurs in rats given high fat food. These changes result in an increase in plasma triglycerides and free fatty acids in the high- sucrose group compared to the high-fat intake group. A study conducted on human studies had shown that carbohydrate restriction can prevent liver steatosis and metabolic syndrome. Furthermore, limiting carbohydrate intake has been shown to be more effective in reducing liver triglycerides than limiting calorie intake in subjects with non-alcoholic fatty liver disease (NAFLD) (Andersen and Fernandez, 2013).

In this study, there was a significant correlation between protein intake and HDL cholesterol levels with significant positive correlation $(\mathrm{r}=0.258)$. This shows that the higher the protein intake, the higher HDL levels would be. Research Dessein et al. (2000) showed similar results that a high-protein carbohydrate restriction diet $(1600 \mathrm{kcal}, 40 \%$ of carbohydrate, $30 \%$ of protein, and $30 \%$ of fat) for 4 months was able to significantly increase HDL levels. A proportional increase in protein intake has been shown to increase insulin sensitivity.

There is a correlation between HDL levels and insulin sensitivity. Most cases of low HDL levels are closely related to conditions of insulin resistance and hypertriglyceridemia. Hypertriglyceridemia conditions often cause insulin resistance which is a trigger in reducing plasma HDL levels. The existence of insulin resistance would cause a disruption in the absorption of free cholesterol in peripheral cells as a result of mutations in the ABC-A1 gene. In addition, insulin resistance also results in impaired free cholesterol esterification as a result of LCAT deficiency (Lecithin Cholesterol Ester Transfer Protein) which is a protein that plays an important role in the formation of HDL, as well as lipoprotein lipase mutations or mutations in the

Table 3. Correlation of energy, fat, carbohydrate, protein, fiber, sodium, saturated fat, and unsaturated fat intake with metabolic syndrome indicators

\begin{tabular}{|c|c|c|c|c|c|c|}
\hline Variables & Waist circumference & GDP & Triglyceride & HDL & Systolic & Diastolic \\
\hline \multirow{2}{*}{ Energy intake } & p: $0.00^{a}$ & $\mathrm{p}: 0.16^{\mathrm{a}}$ & $\mathrm{p}: 0.246^{\mathrm{a}}$ & $\mathrm{p}: 0.62^{\mathrm{a}}$ & $\mathrm{p}: 0.239^{\mathrm{b}}$ & $\mathrm{p}: 0.431^{\mathrm{b}}$ \\
\hline & r: 0.464 & $\mathrm{r}: 0.176$ & r: 0.147 & $\mathrm{r}:-0.063$ & $\mathrm{r}:-0.149$ & $\mathrm{r}:-0.1$ \\
\hline \multirow{2}{*}{ Carbohydrate intake } & $\mathrm{p}: 0.72^{\mathrm{a}}$ & p:0.009 & p: $0.02^{a}$ & $\mathrm{p}: 0.079^{\mathrm{a}}$ & $\mathrm{p}: 0.083^{\mathrm{b}}$ & $\mathrm{p}: 0.122^{\mathrm{b}}$ \\
\hline & $\mathrm{r}: 0.226$ & $r: 0.325$ & $r: 0.372$ & $\mathrm{r}:-0.221$ & $\mathrm{r}:-0.218$ & $\mathrm{r}:-0.195$ \\
\hline \multirow{2}{*}{ Protein intake } & $\mathrm{p}: 0.057^{\mathrm{a}}$ & $\mathrm{p}: 0.977^{\mathrm{a}}$ & $\mathrm{p}: 0.515^{\mathrm{a}}$ & p: $0.04^{a}$ & $\mathrm{p}: 0.345^{\mathrm{b}}$ & $\mathrm{p}: 0.29^{\mathrm{b}}$ \\
\hline & $\mathrm{r}:-0.239$ & $\mathrm{r}: 0.004$ & $\mathrm{r}:-0.083$ & r: 0.04 & $\mathrm{r}:-0.12$ & $\mathrm{r}:-0.134$ \\
\hline \multirow{2}{*}{ Fat intake } & p: $0.00^{a}$ & $\mathrm{p}: 0.558^{\mathrm{a}}$ & p: $0.733^{\mathrm{a}}$ & p: $0.887^{\mathrm{a}}$ & p: $0.432^{b}$ & p: $0.906^{b}$ \\
\hline & r: 0.443 & $\mathrm{r}: 0.075$ & r: 0.043 & $\mathrm{r}:-0.018$ & $\mathrm{r}:-0.1$ & r: 0.015 \\
\hline \multirow{2}{*}{ Fiber intake } & p: $0.704^{\mathrm{a}}$ & $\mathrm{p}: 0.061^{\mathrm{a}}$ & p: $0.086^{\mathrm{a}}$ & $\mathrm{p}: 0.502^{\mathrm{a}}$ & $\mathrm{p}: 0.777^{\mathrm{b}}$ & $\mathrm{p}: 0.611^{\mathrm{b}}$ \\
\hline & $\mathrm{r}:-0.048$ & $\mathrm{r}:-0.235$ & $\mathrm{r}:-0.217$ & $\mathrm{r}: 0.085$ & r: 0.036 & $\mathrm{r}: 0.065$ \\
\hline \multirow{2}{*}{ Sodium intake } & p: $0.389^{\mathrm{a}}$ & $\mathrm{p}: 0.951^{\mathrm{a}}$ & p: $0.994^{\mathrm{a}}$ & $\mathrm{p}: 0.558^{\mathrm{a}}$ & p: $0.668^{b}$ & p: $0.951^{b}$ \\
\hline & r: 0.109 & r: 0.008 & $\mathrm{r}: 0.000$ & r: 0.075 & $\mathrm{r}:-0.055$ & $\mathrm{r}:-0.008$ \\
\hline \multirow{2}{*}{ Saturated fat intake } & $p: 0.664^{a}$ & $\mathrm{p}: 0.466^{\mathrm{a}}$ & $\mathrm{p}: 0.548^{\mathrm{a}}$ & $\mathrm{p}: 0.79^{\mathrm{a}}$ & $\mathrm{p}: 0.699^{\mathrm{b}}$ & $\mathrm{p}: 0.555^{\mathrm{b}}$ \\
\hline & $\mathrm{r}: 0.055$ & $\mathrm{r}: 0.093$ & $\mathrm{r}: 0.077$ & $\mathrm{r}:-0.034$ & r: -0.049 & r: 0.075 \\
\hline \multirow{2}{*}{ Unsaturated fat intake } & $\mathrm{p}: 0.451^{\mathrm{a}}$ & $\mathrm{p}: 0.227^{\mathrm{a}}$ & $\mathrm{p}: 0.176^{\mathrm{a}}$ & $\mathrm{p}: 0.125^{\mathrm{a}}$ & $\mathrm{p}: 0.438^{b}$ & $\mathrm{p}: 0.563^{\mathrm{b}}$ \\
\hline & r: -0.096 & $\mathrm{r}: 0.153$ & $\mathrm{r}:-0.171$ & r: 0.194 & r: -0.099 & $\mathrm{r}:-0.074$ \\
\hline
\end{tabular}

${ }^{\mathrm{a}}$ Pearson, ${ }^{\mathrm{b}}$ Rank Spearman 
apoA-1 gene thereby delaying HDL increase. All of these factors can interfere with HDL catabolism (Rashid et al., 2003). From the causality correlation above, it can be concluded that if there is an increase in protein intake, there will be an increase in insulin sensitivity and decrease insulin resistance and reduce HDL catabolism.

\section{Conclusion}

The most common indicator of metabolic syndrome on women with normal BMI was central obesity and low HDL cholesterol. The factors related to the prevalence of metabolic syndrome on women with normal BMI was macronutrient intake such as fat, protein, and carbohydrate intake. Further research on the relationship of nutrition intake with metabolic syndrome in people with normal body mass index needs to focus on dietary patterns qualitatively to better explain about dietary patterns that are risk factors for metabolic syndrome.

\section{Conflict of Interest}

The authors declare that there is no conflict of interest.

\section{References}

Alkerwi, A. (2014). Diet quality concept. Nutrition, 30 (6), 613-618. https://doi.org/10.1016/ j.nut.2013.10.001

Andersen, C.J. and Fernandez, M.L. (2013). Dietary strategies to reduce metabolic syndrome. Reviews in Endocrine and Metabolic Disorder, 14(3), 241-254. https://doi.org/10.1007/s11154-013-9251-y

Bradshaw, P.T, Monda, K.L. and Stevens, J. (2013). Metabolic syndrome in healthy obese, overweight, and normal weight individuals: the atherosclerosis risk in communities' study. Obesity, 21(1), 203-209. https://doi.org/10.1002/oby.20248

Burini, R.C, Kano, H.T, Nakagaki, M.S, Frenhani, P.B. and Mclellan, K.C.P. (2017). Behavioral factors of abdominal obesity and effects of lifestyle changes with fiber adequacy. New Insights in Obesity: Genetics and Beyond, 1, 14-22. https:// doi.org/10.29328/journal.hodms.1001004

Dessein, P.H, Shipton, E.A, Stanwix, A.E, Joffe, B.I. and Ramokgadi, J. (2000). Beneficial effects of weight loss associated with moderate calorie/carbohydrate restriction and increased proportional intake of protein and unsaturated fat on serum urate and lipoprotein levels in gout: a pilot study. Annals of the Rheumatism Diseases, 59(7), 539-543. https:// doi.org/10.1136/ard.59.7.539

Dodd, J.L. (2012). Nutrition in the Adult Years. In
Mahan, L.K. and Raymond, J.L. (Eds). Krause's Food and the Nutrition Care Process. 13th ed., p. 434. Philadelphia, United States: Elsevier Saunders.

Geetha, L, Deepa, M, Anjana, R.M. and Mohan, V. (2011). Prevalence and clinical profile of metabolic obesity and phenotypic obesity in Asian Indians. Journal of Diabetes Science and Technology, 5(2), 439-446. doi.org/10.1177/193229681100500235

https://

Hizni, A. (2016). Gizi Dewasa. In Hardinsyah and Supariasa, I.D.N. (Eds). Teori dan Aplikasi Ilmu Gizi. 1st ed, p. 209-215. Jakarta: Penerbit Buku Kedokteran EGC. [In Bahasa Indonesia].

He, F., Rodriguez-Colon, S., Fernandez-Mendoza, J. Vgontzas, A.N., Bixler, E.O., Berg, A., Kawasawa, Y.I., Sawyer, M.D. and Liao, D. (2015). Abdominal obesity and metabolic syndrome burden in adolescents-penn state children cohort study. Journal of Clinical Densitometry, 18(1), 30-36. https:// doi.org/10.1016/j.jocd.2014.07.009

Kant, I, Pandelaki, A.J. and Lampus, B.S. (2013). Gambaran kebiasaan makan masyarakat di perumahan allandrew permai kelurahan malalayang I Lingkungan XI Kota Manado. Jurnal Kedokteran Komunitas dan Tropik, 1(3), 88-95. [In Bahasa Indonesia].

Katcher, H.I, Legro, R.S, Kunselman, A.R., Gillies, P.J., Demers L.M., Bagshaw, D.M. and Kris-Etherton P.M. (2008). The effects of a whole grain-enriched hypocaloric diet on cardiovascular disease risk factors in men and women with metabolic syndrome. The American Journal of Clinical Nutrition, 87(1), 79-90. https://doi.org/10.1093/ajcn/87.1.79

Kementrian Kesehatan Republik Indonesia. (2014). Pedoman Gizi Seimbang. Jakarta: Direktorat Jenderal Bina Gizi dan Kesehatan Ibu dan Anak Kementerian Kesehatan RI. Retrieved from http:// ppid-dinkes.sumselprov.go.id/download/109

Lee, S.H., Han, K., Yang, H.K., Kim H.S., Cho, J.H., Kwon H.S., Park, Y.M., Cha, B.Y., and Yoon, K.H. (2015). A novel criterion for identifying metabolically obese but normal weight individuals using the product of triglycerides and glucose. Nutrition and Diabetes, 5(4), e149. https:// doi.org/10.1038/nutd.2014.46

Mutiara, I. (2013). Gambaran sindrom metabolik pada obesitas dan non obesitas di RSUP Haji Adam Malik Medan. Indonesia: Universitas Sumatera Utara. [In Bahasa Indoensia].

Nadimin. (2011). Pola makan, aktivitas fisik, dan status gizi pegawai dinas kesehatan sulawesi selatan. Media Gizi Pangan, XI, 1-6. 
Nikbazm, R., Rafie, M., Ghane basiri, M., Nourshahi, N., Sotoudeh, G., Eshraghian, M., Jalali, M. and Koohdani, F. (2013). The relationship between waist circumference and macronutrient intake in patients with type 2 diabetes in Tehran. International Research Journal of Applied and Basic Sciences, 5 (8), 1021-1024.

Rashid, S., Watanabe, T., Sakaue, T. and Lewis, G.F. (2003). Mechanisms of HDL lowering in insulin resistant, hypertriglyceridemic states: the combined effect of HDL triglyceride enrichment and elevated hepatic lipase activity. Clinical Biochemistry, 36(6), 421-429. https://doi.org/10.1016/S0009-9120(03) 00078-X

Rini, S. (2015). Sindrom metabolik. Medical Journal of Lampung University, 4(4), 88-93.

Sihombing, M. and Tjandrarini, D.H. (2015). Faktor Risiko Sindrom Metabolik pada Orang Dewasa di Kota Bogor. Penelitian Gizi dan Makanan, 38(1), 21 -30. https://doi.org/10.22435/pgm.v38i1.4418.21-30

Song, S.J, Lee, J.E, Song, W.O, Paik, H.Y. and Song, Y.J. (2014). Carbohydrate intake and refined-grain consumption are associated with metabolic syndrome in the Korean adult population. Journal of the Academy of Nutrition and Dietetics, 114(1), 5462. https://doi.org/10.1016/j.jand.2013.08.025

Splett, P.L, and Krinke, U.B. (2011). Adult Nutrition: Conditions and Interventions. In Brown, J.E. (Eds). Nutrition Through the Life Cycle. 4th ed., p. 429448. Belmont: Wadsworth Cengage Learning.

St-Onge, M.-P., Janssen, I. and Heymsfield, S.B. (2004). Metabolic syndrome in normal-weight Americans: new definition of the metabolically obese, normalweight individual. Diabetes Care, 27(9), 2222-2228. https://doi.org/10.2337/diacare.27.9.2222

Suliga, E. Kozie, D, Cieśla, E. and Głuszek, S. (2015). Association between dietary patterns and metabolic syndrome in individuals with normal weight: A Cross-Sectional Study. Nutrition Journal, 14, 55. https://doi.org/10.1186/s12937-015-0045-9

Suliga, E., Koziel, D. and Gluszek, S. (2016). Prevalence of metabolic syndrome in normal weight individuals. Annals of Agricultural and Environmental Medicine, 23(4), 631-635. https:// doi.org/10.5604/12321966.1226858

Sun, J., Buys, N.J. and Hills, A.P. (2014). Dietary pattern and its association with the prevalence of obesity, hypertension, and other cardiovascular risk factors among Chinese older adults. International Journal of Environmental Research and Public Health, 11(4), 3956-3971. https://doi.org/10.3390/ijerph110403956

Thorpe, M.G., Kestin, M., Riddell, L.J., Keast, R.S. and
McNaughton, S. (2014). Diet quality in young adults and its association with food-related behaviours. Public Health Nutrition, 17(8), 1767-1775. https:// doi.org/10.1017/S1368980013001924

Thomas, G.N., Ho, S.Y., Janus, E.D., Lam, K.S.L., Hedley, A.J. and Lam, T.H. (2005). The US National Cholesterol Education Programme Adult Treatment Panel III (NCEP ATP III) prevalence of the metabolic syndrome in a Chinese population. Diabetes Research and Clinical Practice, 67(3), 251 -257. https://doi.org/10.1016/j.diabres.2004.07.022

Zahra, M.A., Aritonang, E.Y. and Ardiani, F. (2013). Gambaran pola makan, aktivitas fisik dan status gizi pada Karyawan UD Alfa Star Busana dan PLS Ervina Medan Tahun 2012. Medan: Gizi Kesehatan Reproduksi dan epidemiologi Perpustakaan Universitas Sumatera Utara. [In Bahasa Indonesia]. 